Nat. Hazards Earth Syst. Sci. Discuss., https://doi.org/10.5194/nhess-2017-295

Manuscript under review for journal Nat. Hazards Earth Syst. Sci.

Discussion started: 28 August 2017

(c) Author(s) 2017. CC BY 4.0 License.

\title{
Application of FLaIR model for early warning system in Chibo Pashyor, Kalimpong, India for rainfall-induced landslides
}

5

\author{
Abhirup Dikshit ${ }^{1}$, Neelima Satyam ${ }^{1}$ \\ ${ }^{1}$ Geotechnical Lab, International Institute of Information Technology, Hyderabad, 500032, India
}

Correspondence to: Abhirup Dikshit (abhirupdikshit@gmail.com)

\begin{abstract}
The development of an early warning system for landslides due to rainfall has become an indispensable part for landslide risk mitigation. This paper explains the application of the hydrological FLaIR (Forecasting of Landslides Induced by Rainfall) model, correlating rainfall amount and landslide events. The FLaIR mode comprises of two modules: RL(Rainfall-Landslide) which correlates rainfall and landslide occurrence and RF (Rainfall-Forecasting) which allows simulation of future rainfall events. The model can predetermine landslides based on identification of mobility function $\mathrm{Y}($.) which links actual rainfall and incidence of landslide occurrence. The critical value of mobility function was analyzed using $1^{\text {st }}$ July 2015 event and applying it to 016 monsoon to validate the results. These rainfall thresholds presented can be improved with intense hourly rainfall and landslide inventory data. This paper describes the details of the model and its performance for the study area.
\end{abstract}

Keywords: Landslide. Hydrological models . Early Warning System

\section{Introduction}

Water is the most important factor in slope instability after gravity (Gerrard 1994). Rainfall and subsequent infiltration affects both stress in slope and strength of materials. Shallow landslides are triggered by small and intense rainfall which causes increase of pore water pressure that decreases the effective stress in soil, thus reducing the shear strength leading to slides whereas deep slides are triggered by extended rainfall of low intensity (Capparelli et al., 2011). There are multiple ways of triggering landslides like weathering, physical and chemical actions induced by water, fluctuation of groundwater level in porous or fractured rocks. The triggering process also depends on whether the slides moves on the pre-existing shear surface or whether it moves for the first time.

A suitable landslide model coupled with measurement of rainfall with a prediction model can result in real time forecasting. Models characterising hydrological phenomena are complex and expensive as many field investigations and surveys are required (Sirangelo et al., 2004). Comparatively simple empirical models are simple and correlates rainfall and landslide occurrence (R-L model) and provides satisfactory results for both risk analysis and real time forecasting.

Most of landslides are due to rainfall and can be referred as precursor in early warning of landslides. The development of Early Warning Systems plays an important role in landslide risk mitigation. The four distinctive times for early warning of landslides are (Capparelli et al., 2011) :

- $\mathrm{t}_{1}$ evolution delay- time between the landslide outset and its impact

- $\mathrm{t}_{2}$ lag- time between precursor occurrence and landslide triggering

- $\mathrm{t}_{3}$ nowcasting delay- time between forecasting and occurrence of the precursor 
Nat. Hazards Earth Syst. Sci. Discuss., https://doi.org/10.5194/nhess-2017-295

Manuscript under review for journal Nat. Hazards Earth Syst. Sci.

Discussion started: 28 August 2017

(C) Author(s) 2017. CC BY 4.0 License.

Natural Hazards

and Earth System

Sciences

Discussions

(c) $($ P)

- $\mathrm{t}$ * intervention delay- time necessary for making decisions and for evacuation.

40 For $\mathrm{t}^{*}<\mathrm{t}_{1}$, monitoring of movement is sufficient. When $\mathrm{t}_{1}<\mathrm{t}^{*}<\left(\mathrm{t}_{1}+\mathrm{t}_{2}\right)$ amount of rainfall must be measured. Finally, when $t^{*}>\left(t_{1}+t_{2}\right)$, rainfall forecasting becomes essential.

The hydrological model for real time forecast of landslides known as FLaIR (Forecasting of Landslides Induced by Rainfalls) was introduced by Sirangelo and Versace (1992). It was developed for simulation and forecasting of landslide movements due to rainfall. FLaIR model allows forecasting by the use of two modules: RL (Rainfall-Landslide) and RF (Rainfall Forecasting). The R-L module correlates precipitation and landslide occurrence. It suggests modelling of hydrological processes, originated due to rainfall which causes changes in pore pressure and may initiate landslides. It identifies relationship between rainfall and landslides by use of mobility function $\mathrm{Y}(\mathrm{t})$, obtained by the convolution of infiltrated rainfalls and transfer function $\psi(\mathrm{t})$. The second module, stochastic rainfall module models the rainfall for probabilistic assessment of mobility function evolution and real time forecasting. The modules when used together enables a probabilistic evaluation of future landslide occurrences (Braca et al., 2002). The hydrological models depend on dates of the historical landslide movement and of rainfall data for calibration which allows real-time forecasting based on monitoring of the rainfall. This model does not require the installation of complex measurement equipment on hillslopes and, therefore, can be applied for landslide detection.

55 There are many variants of the existing hydrological FLaIR model like Generalized FLaIR model (GFM) (De Luca et al., 2016) and MoniFLaIR (Capparelli et al., 2010). The GFM allows to use non stationary thresholds and is able to reproduce all antecedent precipitation models which allows for better prediction of landslide occurrence. MoniFLaIR uses FLaIR index for early warning alarm system which is the ratio of the value of the mobility function reached at time $t$ and threshold value $\mathrm{Y}_{\mathrm{cr}}$.

\section{Study Area}

Kalimpong is one of the hill stations located in the state of West Bengal in India as shown in Fig. 1. It has an average elevation of $1240 \mathrm{~m}$ and is situated on a curved ridge and is hemmed between the Teesta river flowing in the west and Relli river running in the east (Fig. 2). The eastern slopes of Kalimpong are gentler and stable whereas the western face is mostly steep and rugged. The annual temperature in this region ranges from a maximum of $17^{\circ} \mathrm{C}$ to a minimum of $5^{\circ} \mathrm{C}$ (Chatterjee 2010). The severe monsoons in this region cause deadly landslides which isolates the Kalimpong town from rest of the state annually. The soil in Kalimpong is typically reddish in color and at some places they are found with abundant phyllite and schists. 
Nat. Hazards Earth Syst. Sci. Discuss., https://doi.org/10.5194/nhess-2017-295

Manuscript under review for journal Nat. Hazards Earth Syst. Sci.

Discussion started: 28 August 2017

(c) Author(s) 2017. CC BY 4.0 License.
Natural Hazards and Earth System Sciences

Discussions

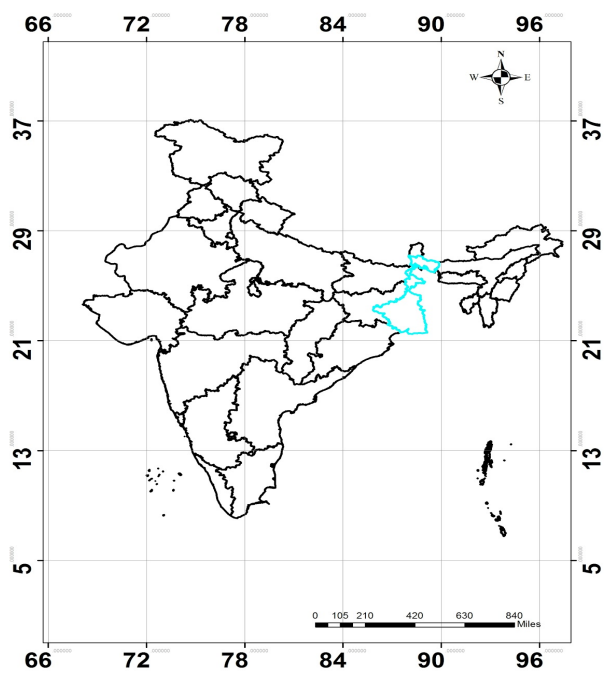

(a)

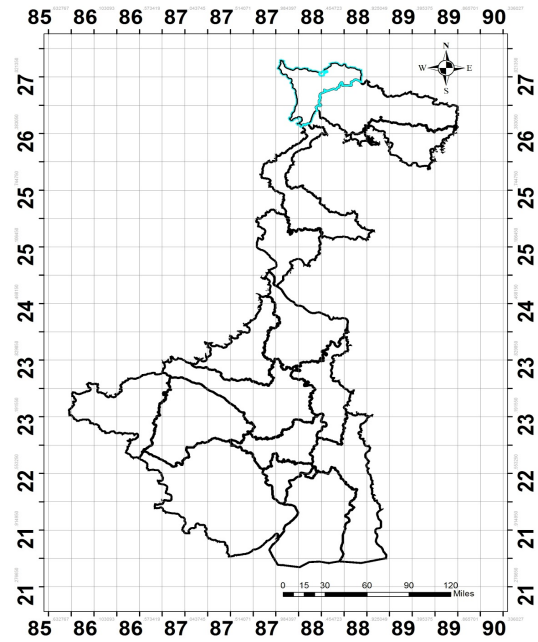

(b)

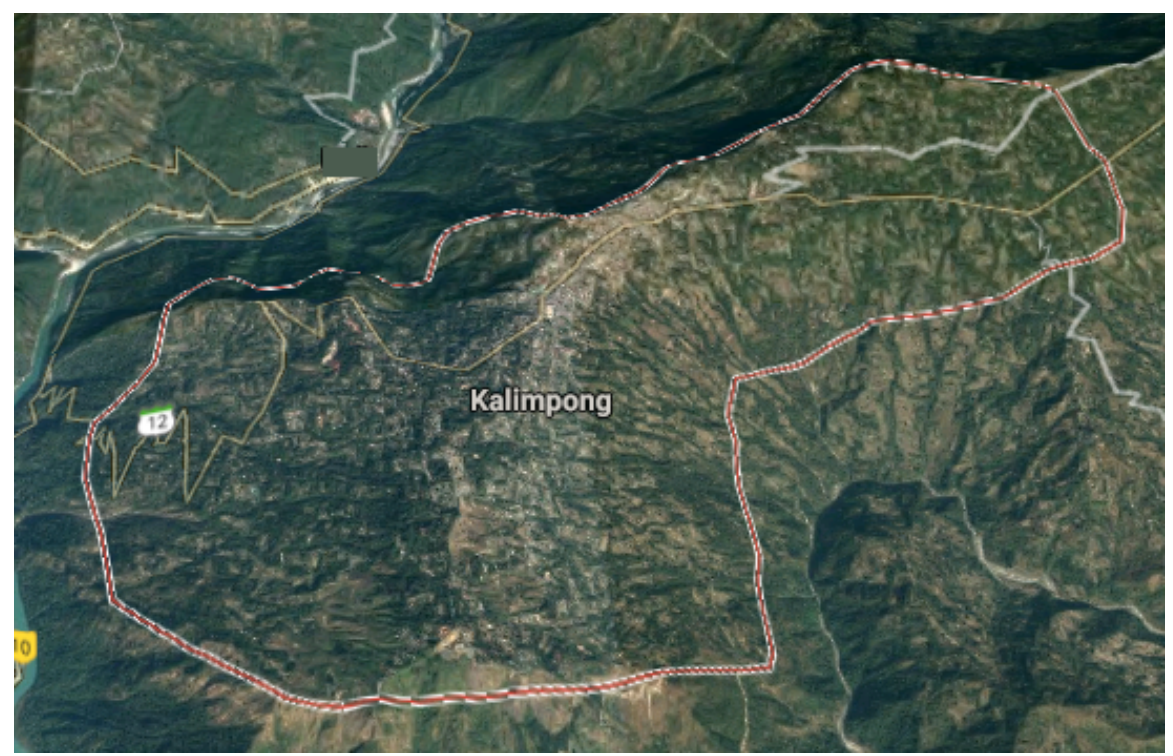

(c)

Figure.1: Location of the study area (a) India (b) West Bengal state (c) Kalimpong town 
Nat. Hazards Earth Syst. Sci. Discuss., https://doi.org/10.5194/nhess-2017-295

Manuscript under review for journal Nat. Hazards Earth Syst. Sci.

Discussion started: 28 August 2017

(c) Author(s) 2017. CC BY 4.0 License.

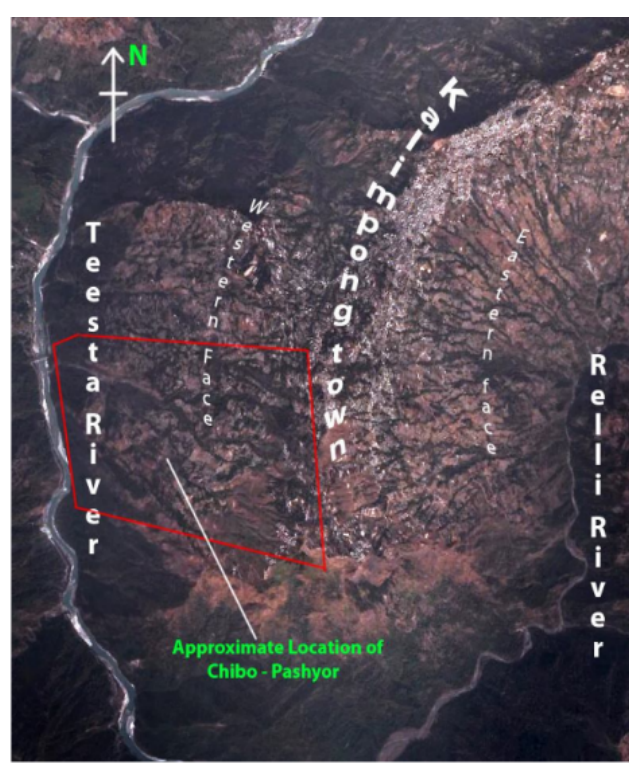

(a)

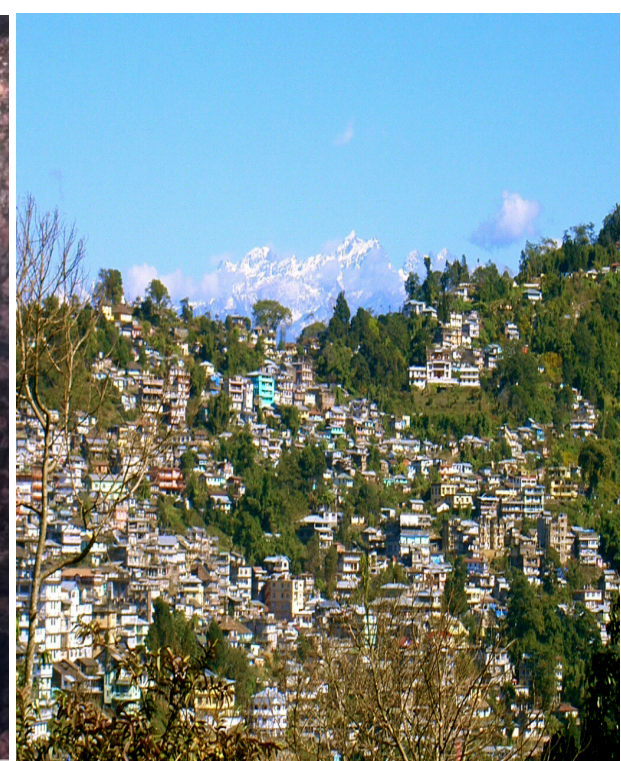

(b)

75 Figure 2: (a) Aerial view of the Kalimpong Town, highlighted portion is present area of investigation (b) Extensive urbanisation in Kalimpong town

The western slope of Kalimpong ridge has been intensely destabilized due to several landslides. These locations contain varying number of translation and debris/rockslides of multiple generations. Landslides are primarily due to poor lithological quality, erosion of river Teesta at the toe and its tributaries within a short time with high intensity rainfall event during monsoon (Chatterjee 2010).

Kalimpong town has an agricultural based economy with extensive paddy cultivation. The cultivation of paddy is a contributing factor towards the occurrence of landslides since it requires large areas of land to be inundated with water for atleast two months. This has lead the farmers move towards alternate crops such as cardamom and floriculture. Agriculture of the region is grossly rainfed and the season is distributed within Pre-Kharif (Indian agricultural season during the months of March-June) and Kharif (Indian agricultural season during the months of July-October) seasons.

The town is around $1053 \mathrm{sq} \mathrm{km}$ of area with the population density of around 40.70 per sq $\mathrm{km}$ (as per Indian census 2011). Rapid expansion of settlements and towns especially along the roads is causing frequent landslides in this area. Multi storied building without proper planning and design along the roads and on steeper slopes increase the load on the already deteriorated slopes.

\subsection{Geology}

Kalimpong town is primarily composed of soft Phyllite, Schists, and Archean gneiss (Chakraborty et al., 2011). The region consists of several cracks, joints that increase the probability of decomposing and disintegrating the rock to form unconsolidated matter. Mountainous soils present in this area are characterised with high organic matter and high water holding capacity which leads to volume expansion. Due to the continuous percolation of water at the bottom layer, the middle portion of the soil horizon is associated with the coarse textures which reduces the shear strength of the soil (Sumantra et al., 2015). The bedrock, throughout the region with minor variation, consists of golden to silver coloured quartz mica schist of Daling series 
Nat. Hazards Earth Syst. Sci. Discuss., https://doi.org/10.5194/nhess-2017-295

Manuscript under review for journal Nat. Hazards Earth Syst. Sci.

Discussion started: 28 August 2017

(C) Author(s) 2017. CC BY 4.0 License.

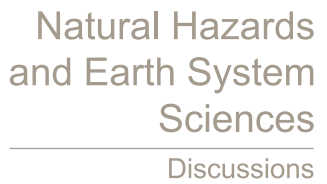

(Mukherjee et al., 2001). The quartz mica schist occasionally grades to dull white mica quartz schist and bright silver white mica schist. The rock, in general, is metamorphosed up to the biotite zone, while garnet starts appearing near the eastern margin. The beds dips towards the east and northeast with inclination varying from $20^{\circ}$ near the Teesta to about $40^{\circ}$ towards town. Three sets of joints are present in most of the rocks, one parallel, one perpendicular and the last, oblique to foliation. The landslides in the area are controlled to a great extent, by the foliation of the schist and by local enrichment of micaceous minerals. Kalimpong is in the Himalayan Belt, one of the most earthquake prone areas in the world. There hasn't been a major earthquake exceeding magnitude of 8 in the last 50 years. (Mukherjee et al., 2001). The typical geological stratigraphy of the Kalimpong town is shown in Fig. 3 (modified from Acharya,1968).

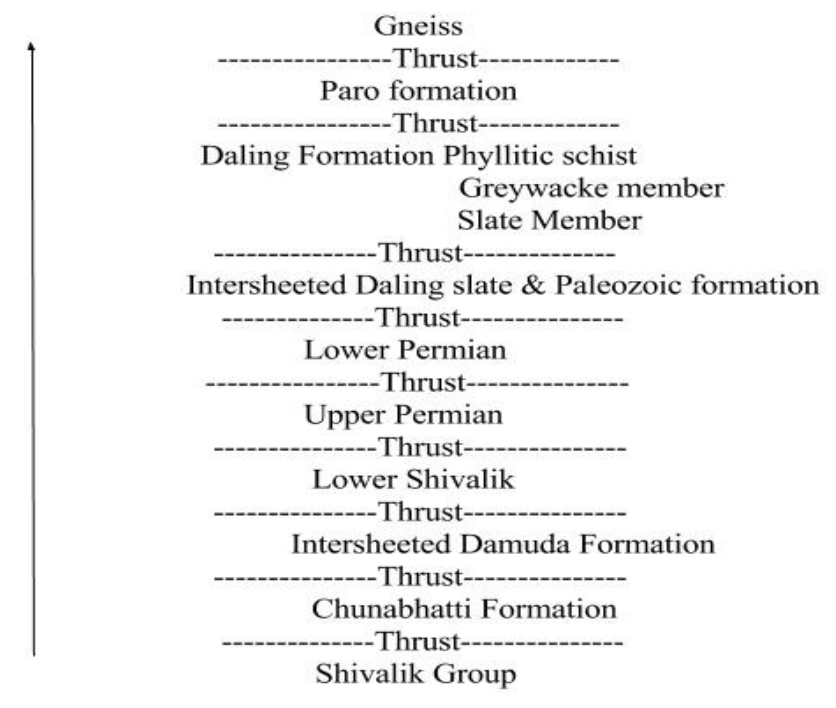

Figure 3: The stratigraphic sequence of Kalimpong town (modified from Acharya. 1968)

\subsection{Geohydrology}

The entire area has five sub-basins all flowing down as the tributaries of the Teesta river (Mukherjee et al., 2001). The entire Teesta basin consists of first order streams that join to form second and higher order streams (Fig. 4). Often these first order streams are seen to be disappearing at a point and then reappearing somewhere down slope. The major streams are mostly perennial, fed by the rain water and percolating ground water. 
Nat. Hazards Earth Syst. Sci. Discuss., https://doi.org/10.5194/nhess-2017-295 Manuscript under review for journal Nat. Hazards Earth Syst. Sci.

Discussion started: 28 August 2017

(C) Author(s) 2017. CC BY 4.0 License.

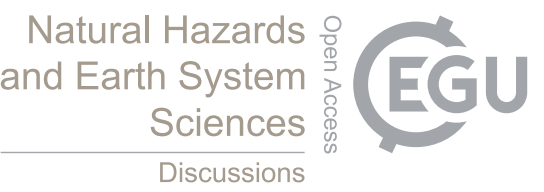

115

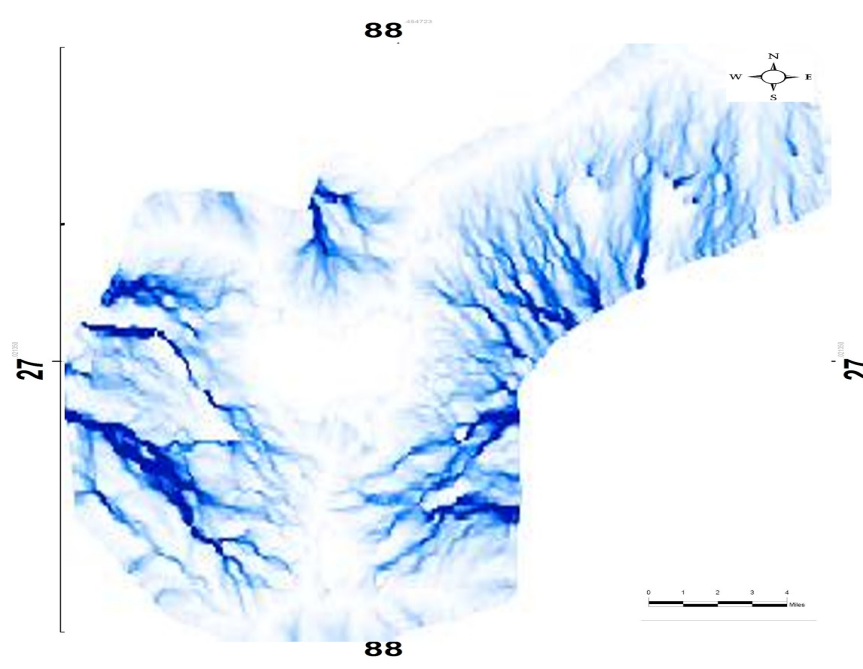

Catchment Area

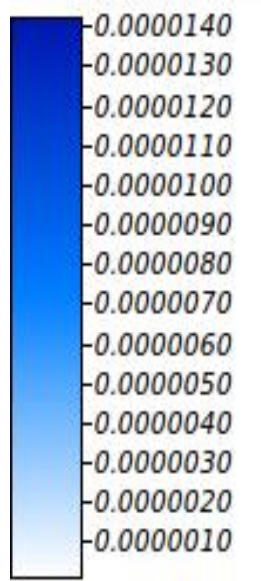

Figure 4: Drainage Map of Kalimpong town

Most of the eastern slope streams downslope while the western slope streams flows parallel through deep narrow valleys upto Teesta. The morphometric classification of the slope shows moderately steep slope category $\mathrm{C}$ $\left(20^{\circ}-30^{\circ}\right)$ to predominate the slope, followed by gentle slope category $\mathrm{D}\left(10^{\circ}-20^{\circ}\right)$ and the steep slope category B $\left(30^{\circ}-45^{\circ}\right)$ to predominate the slope (Mukherjee et al., 2001). During monsoon these young streams flow with great vigour causing frequent floods and carrying down an unsorted load of small pebbles to huge boulders. This causes intense lateral and headward erosion which results into successive bank failures mostly in the form of severe landslides. The rainfall during the monsoon in Kalimpong happens in pockets and is the most high time for landslide activity in this study region.

Table 1. The rainfall data (in mm) during the four monsoon months in Kalimpong town (2010-2016)

\begin{tabular}{|c|c|c|c|c|c|c|c|}
\hline Month & $\mathbf{2 0 1 0}$ & $\mathbf{2 0 1 1}$ & $\mathbf{2 0 1 2}$ & $\mathbf{2 0 1 3}$ & $\mathbf{2 0 1 4}$ & $\mathbf{2 0 1 5}$ & $\mathbf{2 0 1 6}$ \\
\hline June & 316.8 & 337 & 354.9 & 248 & 396.4 & 568 & 327.2 \\
\hline July & 665.4 & 678 & 433.1 & 424.6 & 371.2 & 534.4 & 869.8 \\
\hline August & 425.3 & 525.6 & 250.8 & 401 & 571.8 & 242.3 & 262.6 \\
\hline September & 268.2 & 384.1 & 467.9 & 113 & 265.4 & 331.2 & 366.8 \\
\hline
\end{tabular}


Nat. Hazards Earth Syst. Sci. Discuss., https://doi.org/10.5194/nhess-2017-295

Manuscript under review for journal Nat. Hazards Earth Syst. Sci.

Discussion started: 28 August 2017

(C) Author(s) 2017. CC BY 4.0 License.

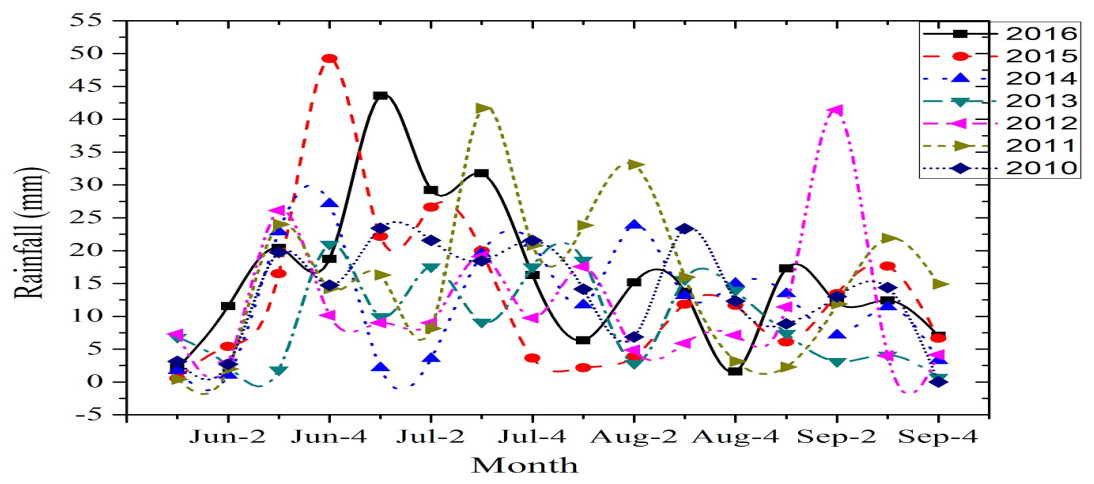

Figure 5: Rainfall data during the monsoon season (June-September) (2010-2016)

\section{Major Causes of Landslides in Kalimpong}

Kalimpong is located in the Shivalik Himalayan range which is a young fold mountain with lateritic soil and active tectonic plate movement making it vulnerable to landslides. Kalimpong has a history of landslides with the first one recorded in 1899 and the major one in 1968 (Source: GSI). The triggering of landslides also dwells on the occurrence of earthquakes as the region lies in Zone 4 which is considered as high risk zone according to seismic microzonation map of India by Bureau of Indian Standards(BIS) in 2000. During the period of 2010-2016 total of 99 landslide events occurred out of which 61 landslides were due to rainfall.

\subsection{Rainfall}

Rainfall plays an important role in landslide activity in this region as heavy rainfall loosens up the soil by breaking of bonds and particle disintegration. The water movement along the banks of streams and rivers also causes weathering of rocks. Over prolonged period of time the rock and other material becomes weak and fails leading to slides. Fig. 4 shows the drainage map of Kalimpong town with a radially outward drainage pattern.

Due to heavy rainfall the sloped surface area becomes totally saturated following a landslide. As soil absorbs water, the unit area increases which appends to the total weight of the soil which increases the chances of landslides due to hike in pore pressure (McGeary et al., 2001). It triggers landslides through percolation of water in joints and cracks. Rain acts as lubricant that induces the occurrence of landslides. Rainfall lubricates the materials slip off from the parent body and moves downward under the force of gravity. The percolation of water through soil pore space accelerates the probability of occurrence. Water triggers landslides because it's heavy and adds extra weight which makes the soil, rock to succumb to the forces of gravity.

The rainfall data was collected from Geological Survey of India (GSI), Kolkata for Kalimpong town during 2010-2016 as shown in Table 1. The water movement also causes weathering of rocks along the banks of streams and rivers. Over long periods of time such processes cause the rock and other material to fail leading to slides. As the drainage line increases, frequency of landslide decline as the seepage near the drainage network is directly proportional to the distance, so the shear strength of the soil is reduced near the drainage network (Rajakumar et al., 2007) . The rainfall during the monsoon in Kalimpong happens in pockets and is the most high time for landslides in this region. Fig. 5 shows the rainfall data between June and September months from 2010-2016 which has been considered for the analysis. 
Nat. Hazards Earth Syst. Sci. Discuss., https://doi.org/10.5194/nhess-2017-295

Manuscript under review for journal Nat. Hazards Earth Syst. Sci.

Discussion started: 28 August 2017

(c) Author(s) 2017. CC BY 4.0 License.

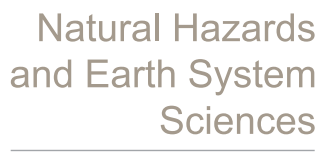

Discussions

The Kalimpong ridge is rugged in topography and is dissipated by radically descending rivulets that contribute to the Teesta river basin. Network of small tributaries along the Kalimpong ridgeline turn empty into 4-5 major natural rivulets also known as jhoras in this area. These major jhoras are causing intense scouring and loss of land to farmers. The human activities such as the non-engineering uses of the slope for construction, deforestation and the development of towns and tourism industry are also responsible for the increase of landslide in this region.

The jhoras have their source at the top of the hill and are fed initially by water from an abundant number of perennial natural springs which exists in the upper part of the hill. The water during the monsoon is enhanced by huge amounts of surface runoff from the rapidly expanding areas. Untrained jhoras have been a havoc for people as they have become a primary reason for increased landslides and have lead to more number of sinking areas in the region. The major streams are mostly perennial, fed by the rain water and percolating ground water. During monsoon these young streams flow with great vigour causing frequent floods and carrying down an unsorted load of small pebbles to huge boulders. Urban areas expand on the upper reaches of the hill, the expanse of concrete and asphalt in these areas does not permit percolation of rainwater into the soil and a large part of precipitation drains out as surface runoff. The absence of planned drainage system in the new built up areas allows this water to find a path into many natural tributaries which eventually feed the major jhoras. This causes intense lateral and headward erosion which results into successive bank failures mostly in the form of large landslide (http://savethehills.blogspot.in/2010/03/1.html).

\section{Landslide Prediction}

215 Prediction of landslide triggering is a primitive step in setting up of early warning system. Prediction can be based on the analysis and elaboration of pore pressure changes in subsoil, ground displacements or both. In countries like Hong Kong (Finlay et al., 1997), California (Wilson \& Wieczorek, 1995), New Zealand (Glade et al., 2000) thresholds have been established by collecting rainfall and landslide data resulting in landslides. Such thresholds depend on a combination of rainfall intensity and duration; which leads to decrease in critical intensity as the rainfall duration increases. The relationship between landslide occurrence and rainfall characteristics varies from site to site. Because of the prominent role of slope morphology, stratigraphy and soil properties, in Kalimpong the approach can be applied only at a regional scale.

\subsection{FLaIR Model}

The FLaIR (Forecasting of Landslides Induced by Rainfall) model as name suggests is applicable to landslides triggered by rainfall. For each regular study event, the mobility function $\mathrm{Y}(\mathrm{t})$ is derived by linking the rainfall intensity I(t) and filter function $\psi(\mathrm{t})$ to determine the slope stability (Capparelli et al., 2011). In the hydrological model FLaIR suggested by Sirangelo and Versace (1992) mobility function has been considered as convolution between the rainfall intensity $\mathrm{I}(\mathrm{t})$ and a filter function $\psi(\mathrm{t})$. Mobility function $\mathrm{Y}(\mathrm{t})$ is a generic function of the antecedent rainfall which is correlated with landslide occurrence and can also be taken as an indicator of slope stability conditions to be compared with reference critical values.

FLaIR model consists of two modules. The first one, indicated as "Rainfall - Landslide" module, correlates precipitation and landslide occurrence. It suggests a simple conceptual modelling of the hydrological processes that, beginning from the rainfall, produce variation in the hill-slope pressure field and then may trigger a landslide. This module enables model calibration and permits the reproduction of historical movements. The second one, called "Stochastic Rainfall" module, provides a tool for real-time forecasting. It allows probabilistic evaluation of rainfalls by reproducing the behaviour of the observed data. This module, in conjunction with the "Rainfall -Landslide" module, enables a probabilistic evaluation of future landslide occurrence. 
Nat. Hazards Earth Syst. Sci. Discuss., https://doi.org/10.5194/nhess-2017-295

Manuscript under review for journal Nat. Hazards Earth Syst. Sci.

Discussion started: 28 August 2017

(c) Author(s) 2017. CC BY 4.0 License.

Natural Hazards

and Earth System

Sciences

Discussions

FLaIR model connects mobility function value $\mathrm{Y}(\mathrm{t})$ to the probability $\mathrm{P}[\mathrm{E}(\mathrm{t})]$ at time $\mathrm{t}$ as:

$P[E(t)]=F[Y(t)]$

If $\mathrm{P}\left[\mathrm{E}_{\mathrm{t}}\right]$ is the probability of occurrence of a landslide at time $\mathrm{t}$, and assuming that $\mathrm{P}\left[\mathrm{E}_{\mathrm{t}}\right]$ depends only on $\mathrm{Y}(\mathrm{t})$, $\mathrm{P}\left[\mathrm{E}_{\mathrm{t}}\right]$ can be expressed as:

$$
\begin{aligned}
& P\left[E_{t}\right]=\left\{0 \text { if } Y(t)<Y_{\lim }\right. \\
& 1 \text { if } Y(t)>Y_{\lim }
\end{aligned}
$$

where $\mathrm{Y}_{\text {lim }}$ is the value of the mobility function which identifies the critical conditions for a slope. There is a null probability (impossible event) for values less than $Y_{\lim }$ and a probability equal to 1 (certain event) for greater values.

The mobility function $\mathrm{Y}(\mathrm{t})$ can be defined as:

$$
Y(t)=f[I(s)]
$$

Where $\mathrm{I}(\mathrm{s})$ is infiltration rate.

Assuming linear behaviour of model, mobility function can be expressed as :

$$
\mathrm{Y}(\mathrm{t})=\mathrm{k}_{0} \int_{-\infty}^{t} \psi(t-s) I(s) d s
$$

$\psi(\mathrm{t})$ is a filter function and $\mathrm{k}_{0}$ is constant which depends on characteristics of groundwater. The FLaIR model adopts a simpler relationship between rainfall and infiltration:

$$
\begin{aligned}
\mathrm{I}(\mathrm{s})=\mathrm{cP} \mathrm{P}^{\prime}(\mathrm{s}) \quad \mathrm{P}^{\prime}(\mathrm{s})= & \left\{\mathrm{P}(\mathrm{s}) \text { if } \mathrm{P}(\mathrm{s}) \leq \mathrm{P}_{0}\right. \\
& \mathrm{P}_{0} \text { if } \mathrm{P}(\mathrm{s})>\mathrm{P}_{0}
\end{aligned}
$$

The function $\psi($ (.) is typical for each case study and plays a central role in mobility function evaluation. It can assume different expressions (Iiritano et al., 1998), such as:

Rectangular: $\psi(t)=\left\{1 / t_{0}\right.$ if $\left.0 \leq t \leq t_{0}\right\}$

$$
0 \text { elsewhere }
$$

Exponential: $\psi(t)=1 / k e^{-1 / k} t \geq 0 ; k>0$

Gamma: $\psi(t)=b^{a} / \Gamma(a) t^{a-1} e^{-b t} \quad t \geq 0 ; a>0 ; b>0$

Power: $\psi(t)=m t^{-q} 0<t<T ; m>0 ; 0<q<1$

Mixture of two exponential functions:

$\psi(t)=\omega \beta_{1} \exp \left(-\beta_{1} t\right)+(1-\omega)\left(-\beta_{2} t\right)$

Mixture of two exponential functions is very flexible and allows for two different kinds of rainfall interaction: the first part reproduces the effect of the most recent rainfall (short-term component); the second part reproduces the effects also of earlier rainfalls (long-term component). The terms $\omega$ and $(1-\omega)$ represent the weights of the two components (Capparelli et al., 2011).

\subsection{Transfer function}

The transfer function or filter $\psi($.$) correlates the rainfall infiltration and probability of landslide movements,$ varying with each event of landslide. In FLaIR Model, different mobility functions may be obtained by considering different transfer functions for the same rainfall pattern.

On the basis of time intervals, rainfall-induced landslides can be classified as follows: 
Nat. Hazards Earth Syst. Sci. Discuss., https://doi.org/10.5194/nhess-2017-295

Manuscript under review for journal Nat. Hazards Earth Syst. Sci.

Discussion started: 28 August 2017

(C) Author(s) 2017. CC BY 4.0 License.

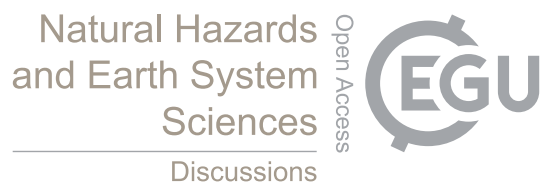

(c) (i)

- Shallow Slips- For shallow slips the trigger is caused by very intense rainfall accumulated on short time intervals

- Deep Landslides- For deep landslides the triggering process also depends on rainfall accumulated on long time intervals.

The transfer function which leads the mobility function $\mathrm{Y}(\mathrm{t})$ to reach its maximum value in correspondence to date when the slope instability occurred will be used. Similarly, if the reactivation dates are repeated over time, the mobility function should attain its $\mathrm{n}$ highest values in relation to $\mathrm{n}$ historical movement dates. Therefore, the convolution equation (Eq. 3) is solved by adopting different transfer functions and selecting the one that satisfies the condition. The FLaIR model was applied to landslides in this region, obtaining each shape of the transfer function and the trend of the mobility function (Fig. 6).

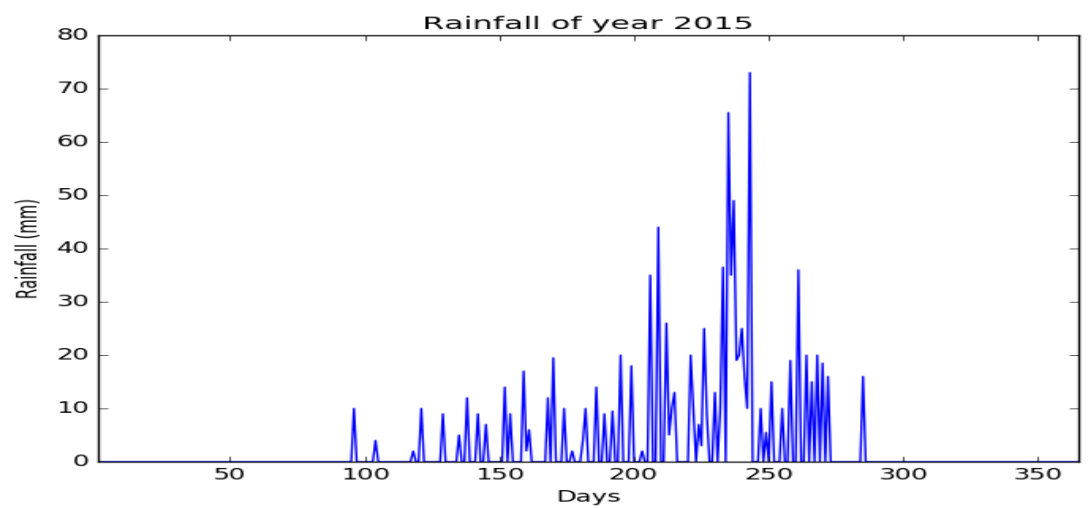

(a)
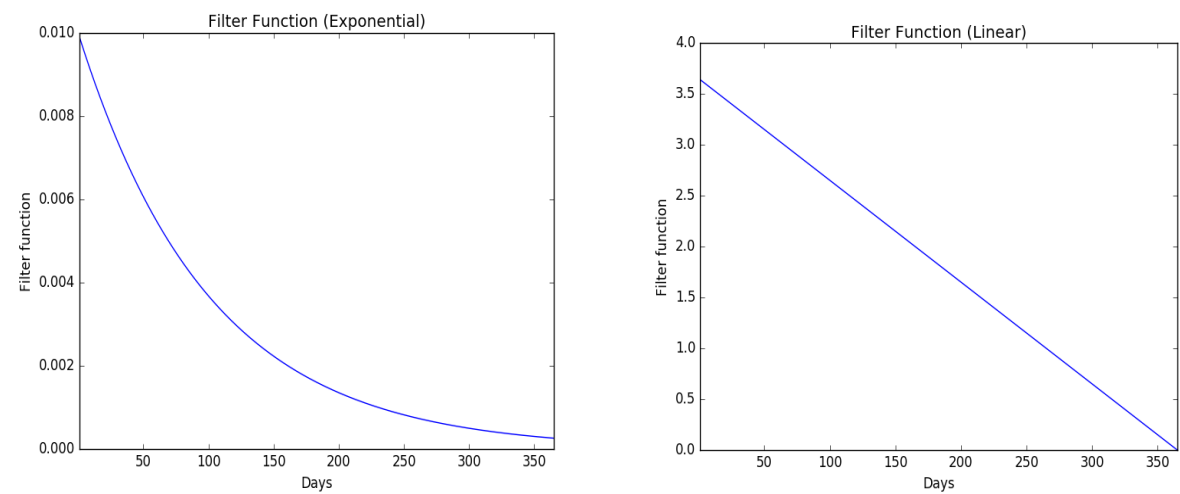
Nat. Hazards Earth Syst. Sci. Discuss., https://doi.org/10.5194/nhess-2017-295

Manuscript under review for journal Nat. Hazards Earth Syst. Sci.

Discussion started: 28 August 2017

(c) Author(s) 2017. CC BY 4.0 License.
Natural Hazards

and Earth System

Sciences

Discussions

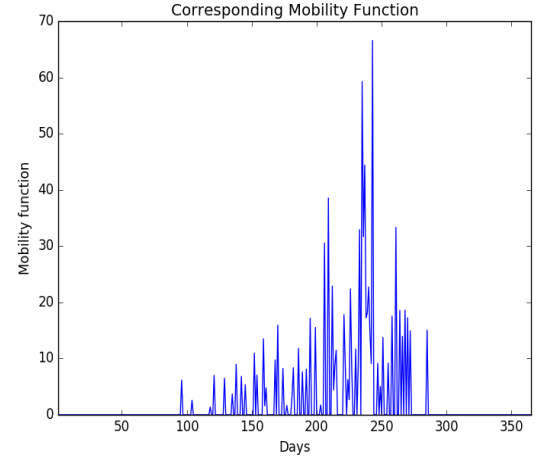

(d)

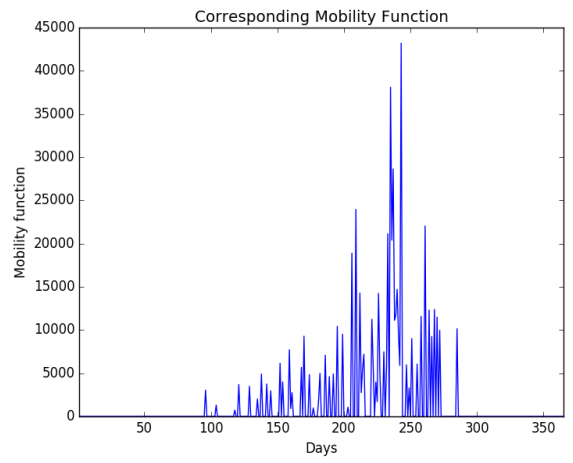

(e)

Figure 6 Figure (a,b,c,d,e): shows that for the same rainfall pattern(a), different mobility functions were obtained using different transfer functions

\section{Case study of Chibo Pashyor landslide (2015), Kalimpong}

Chibo Pashyor region is located in the south-western tip of the Kalimpong town ridge-line.The village comprises of around 5000 people living in 1200 houses or so which are spread over a large farming area . Three large jhoras and a large number small tributaries plough through the Chibo area. The biggest and most destructive is Magar jhora. The damage done by this jhora is immense and threatens the entire region. The other two big jhoras which ravage Chibo are Chibo School jhora and Paireyni jhora (Source: Save The Hills). Figure 7 shows Chibo Pashyor study area with the streams which causes landslides in this region.

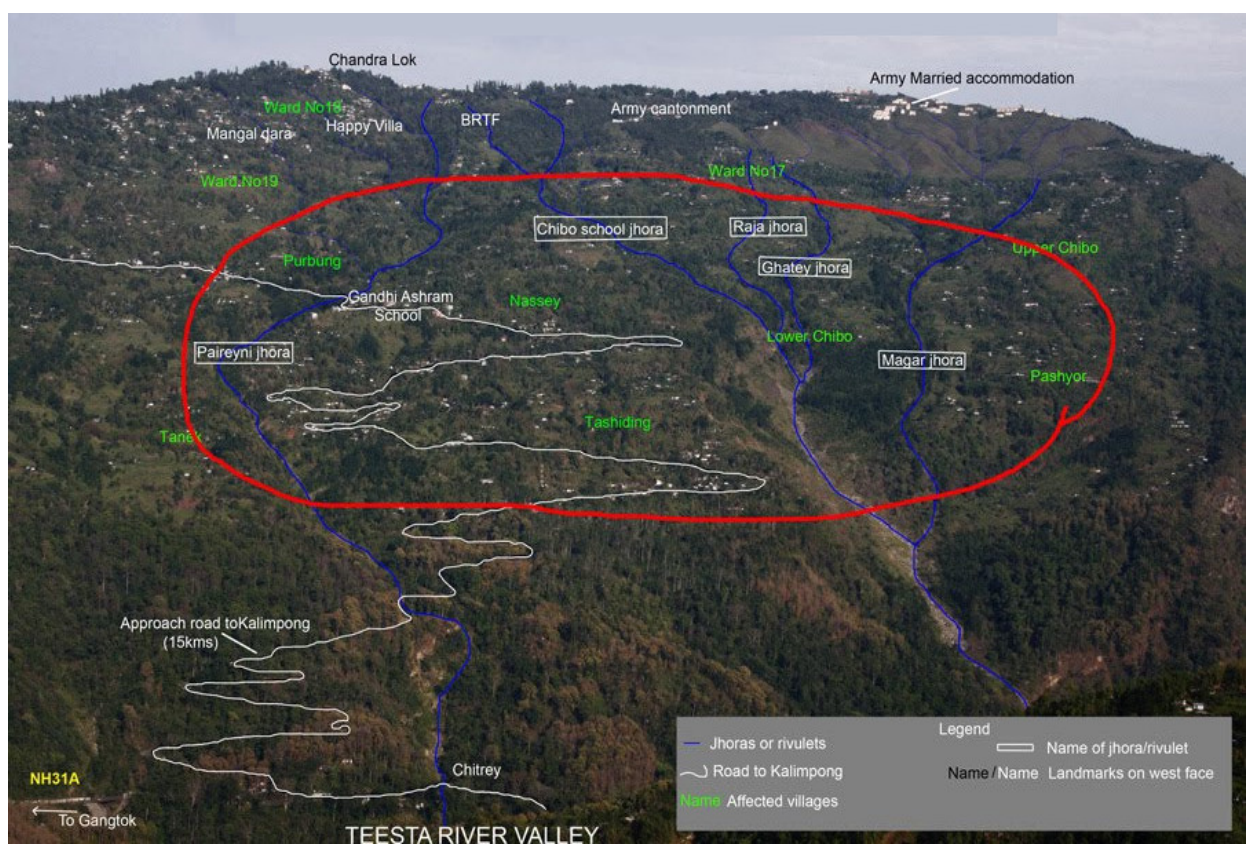

Figure 7: View of Chibo Pashyor area with the jhoras and areas affected 
Nat. Hazards Earth Syst. Sci. Discuss., https://doi.org/10.5194/nhess-2017-295

Manuscript under review for journal Nat. Hazards Earth Syst. Sci.

Discussion started: 28 August 2017

(c) Author(s) 2017. CC BY 4.0 License.
Natural Hazards and Earth System Sciences

Discussions

(c) $\underset{\mathrm{BY}}{(i)}$

\subsection{Implementation of FLaIR model}

On $1^{\text {st }}$ July 2015 torrential rains lashed Chibo Pashyor causing catastrophe in the area. Rainfall amount registered closest to this region was about $227 \mathrm{~mm}$ in 2 days. Figure 8 shows the landslide damages occurred on 1st July 2015 at Chibo Pashyor. This event was considered to calculate the critical mobility values which would be useful to generate warning system for the region. The filter form identified for this landslide was the mixture of two exponential functions as shown in Eq. 10. The values of $\omega, 1 / \beta_{1}$ and $1 / \beta_{2}$ was considered as $0.1,0.75$ days and 150 days (Braca et al., 2002). The region has characteristics of Precambrian mantle, therefore a value $\mathrm{P}_{0}=16.5 \mathrm{~mm} / \mathrm{h}$ was adopted for the analysis.

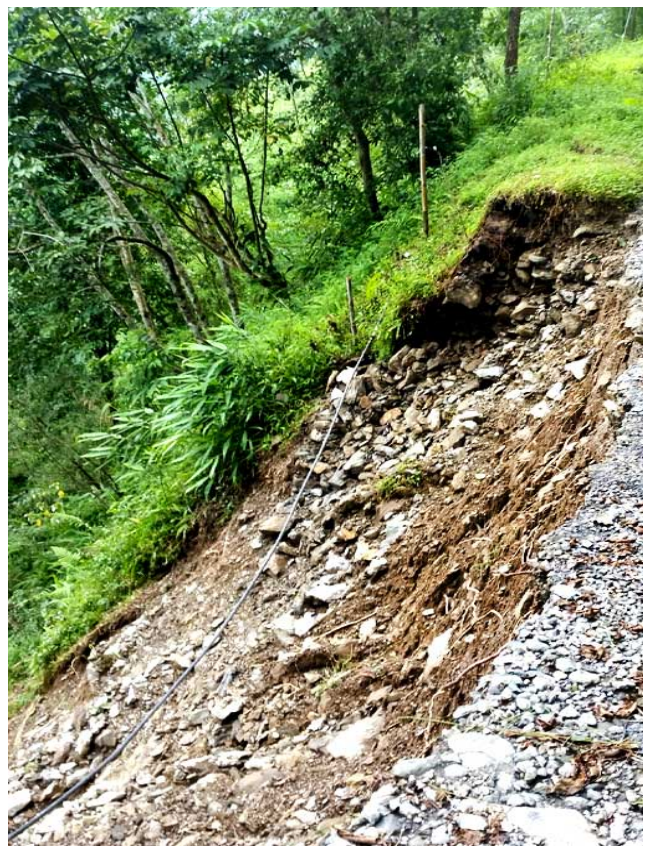

(a)

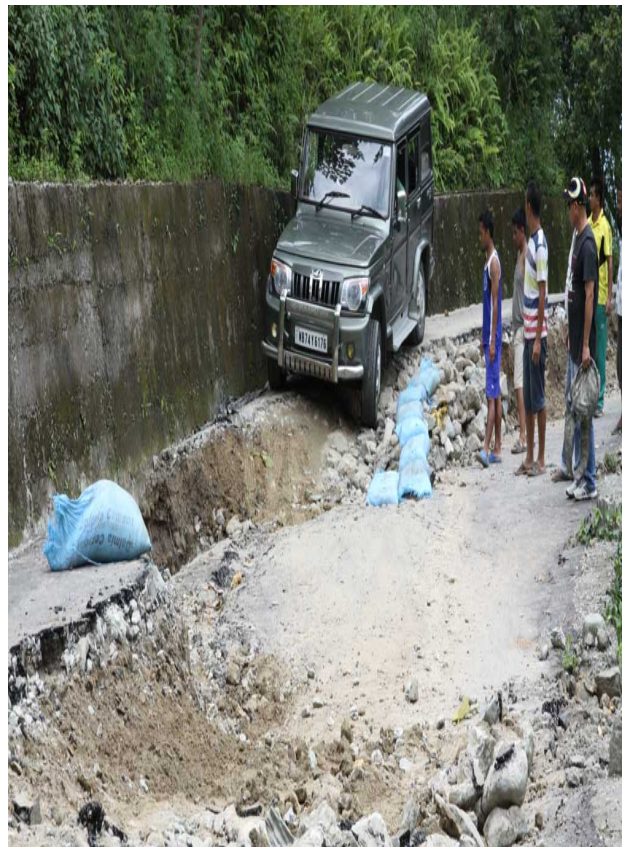

(b)

Figure 8(a, b): Landslide damages on July ${ }^{\text {st }}, 2015$ at Chibo Pashyor

The behaviour of the filter function is illustrated in Fig. 9. The physical process that initiated the earth movement is in accordance with the structure of the filter function. Such phenomena is marked by two methods associated to precipitation infiltrating the subsurface, but having two different time scales.(Chirico et al., 2000) 
Nat. Hazards Earth Syst. Sci. Discuss., https://doi.org/10.5194/nhess-2017-295

Manuscript under review for journal Nat. Hazards Earth Syst. Sci.

Discussion started: 28 August 2017

(C) Author(s) 2017. CC BY 4.0 License.

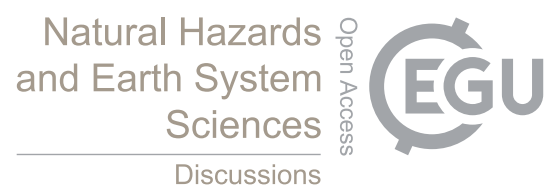

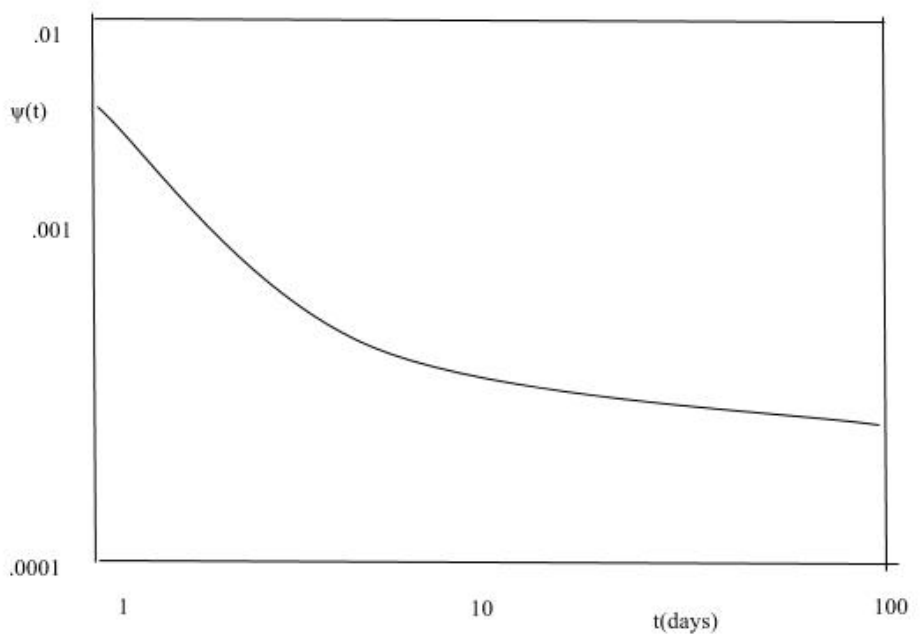

Figure 9: Filter function adopted for July $1^{\text {st }} 2015$ Chibo Pashyor landslide event.

In the present study, the mobility function using the filter function during June 1 to September 30, 2015 (Fig. 10a) was performed every day, considering the precipitation was cumulated over a period of 24 hours. Mobility function reached its maximum value of $\mathrm{Y}_{\lim }=0.27$ (Fig. 10b).

\section{Precipitation vs Date}

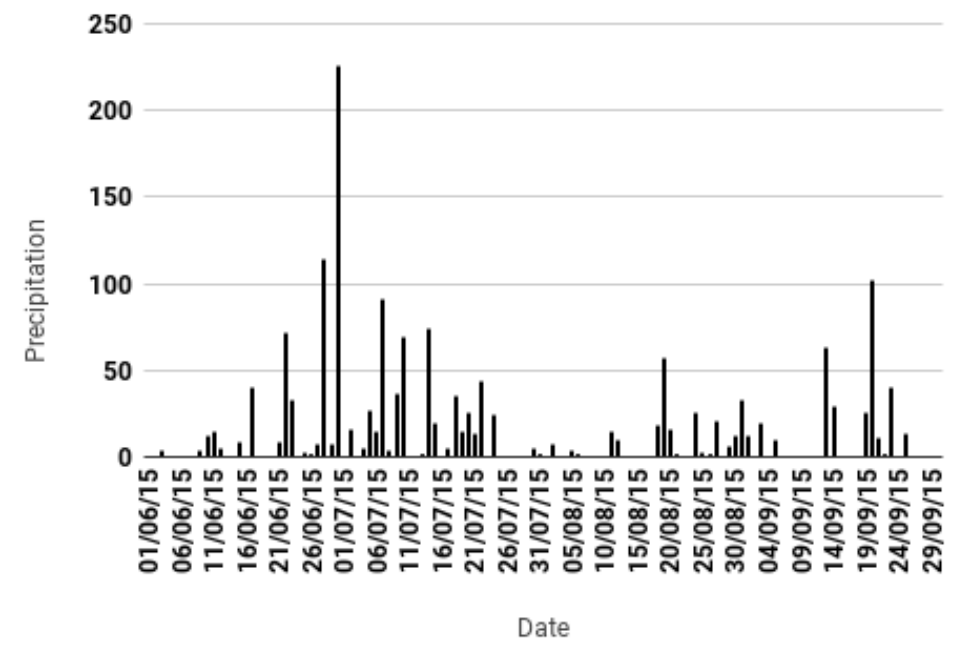

(a) Precipitation values during June 1 to September 302015 
Nat. Hazards Earth Syst. Sci. Discuss., https://doi.org/10.5194/nhess-2017-295

Manuscript under review for journal Nat. Hazards Earth Syst. Sci.

Discussion started: 28 August 2017

(c) Author(s) 2017. CC BY 4.0 License.
Natural Hazards and Earth System

Sciences

Discussions

(c) $\underset{\mathrm{By}}{(i)}$

Mobility Function $\mathrm{Y}(\mathrm{t})$ vs Date

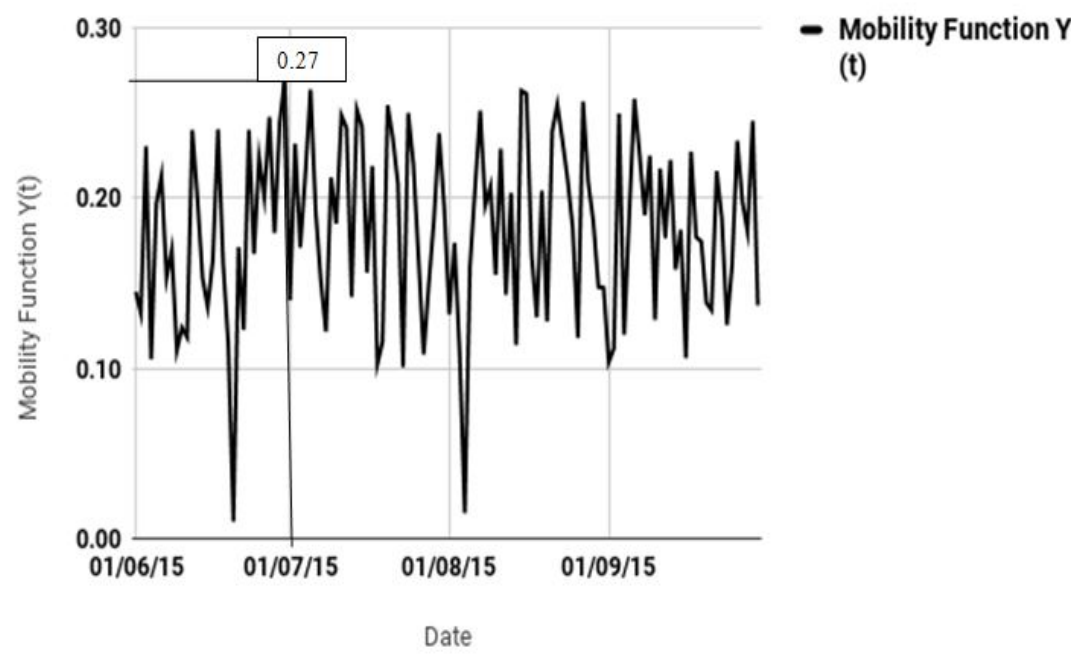

(b) Mobility function between 01 June 2015- 30 September 2015

Fig 10(a,b) Precipitation values and its corresponding mobility values from 1 June 2015 to 30 September 2015

5.2 Warning System

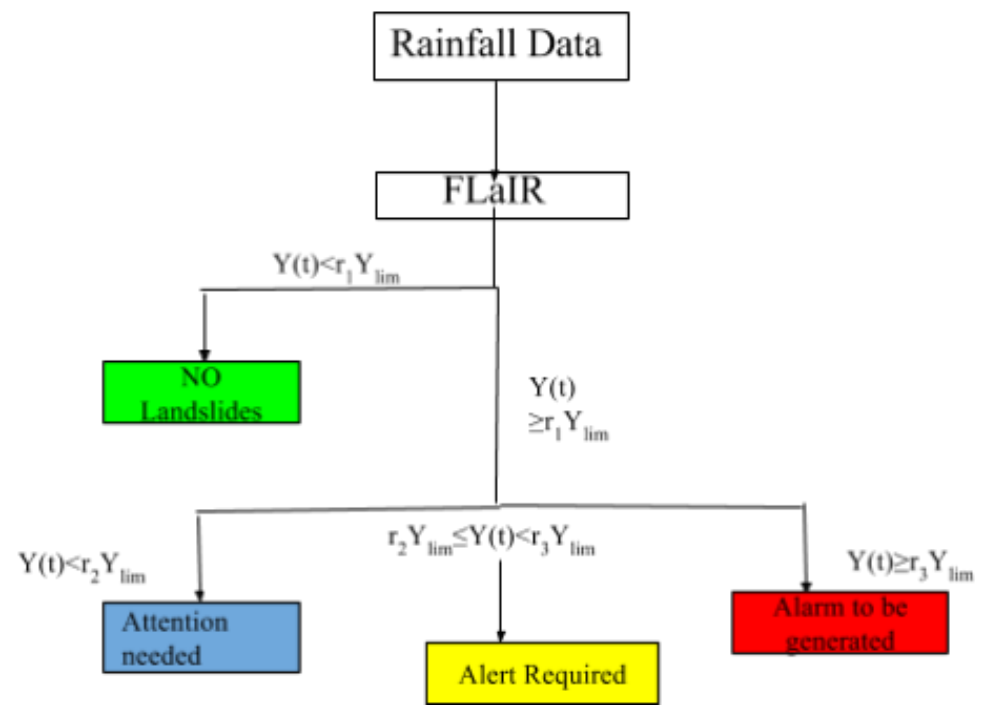

Figure 11: Flowchart representing warning system using FLaIR model for Chibo Pashyor

The flowchart of a warning system using FLaIR model is expressed in Fig. 11. To bring down the risk level during landslide following three plan of action needs to be taken by civil protection agencies: 
Nat. Hazards Earth Syst. Sci. Discuss., https://doi.org/10.5194/nhess-2017-295

Manuscript under review for journal Nat. Hazards Earth Syst. Sci.

Discussion started: 28 August 2017

(c) Author(s) 2017. CC BY 4.0 License.

- attention status, using real-time monitoring instrumentation like tiltmeters, inclinometers etc.

- alarm status, involving population for evacuation.

A characteristic mobility ratio $\mathrm{r}=\mathrm{Y} / \mathrm{Y}_{\lim }$ is associated at each stage of the warning system.

FLaIR model can be used in two distinctive ways for effective warning system. First being the "Rainfall Landslide" module, every warning status is activated when a fixed value of mobility ratio is exceeded. Other being the "Stochastic Rainfall" module, every warning status is activated when the probability of the mobility ratio exceeds value in fixed forecasting time (Braca et al., 2002).

The necessities of selecting the mobility ratio values linked up with each warning level are opposite and two-fold: (1) there is a need to have sufficient safety margins i.e., low values of mobility ratio and (2) minimum or no false alarms to prove its reliability which means high mobility ratios. In this application, the attention ratio $\left(r_{1}\right)$ of 0.4 , alert ratio $\left(r_{2}\right)$ of 0.6 , and alarm ratio $\left(r_{3}\right)$ of 0.8 was assumed (Braca et al., 2002)

\section{Precipitation vs Date}

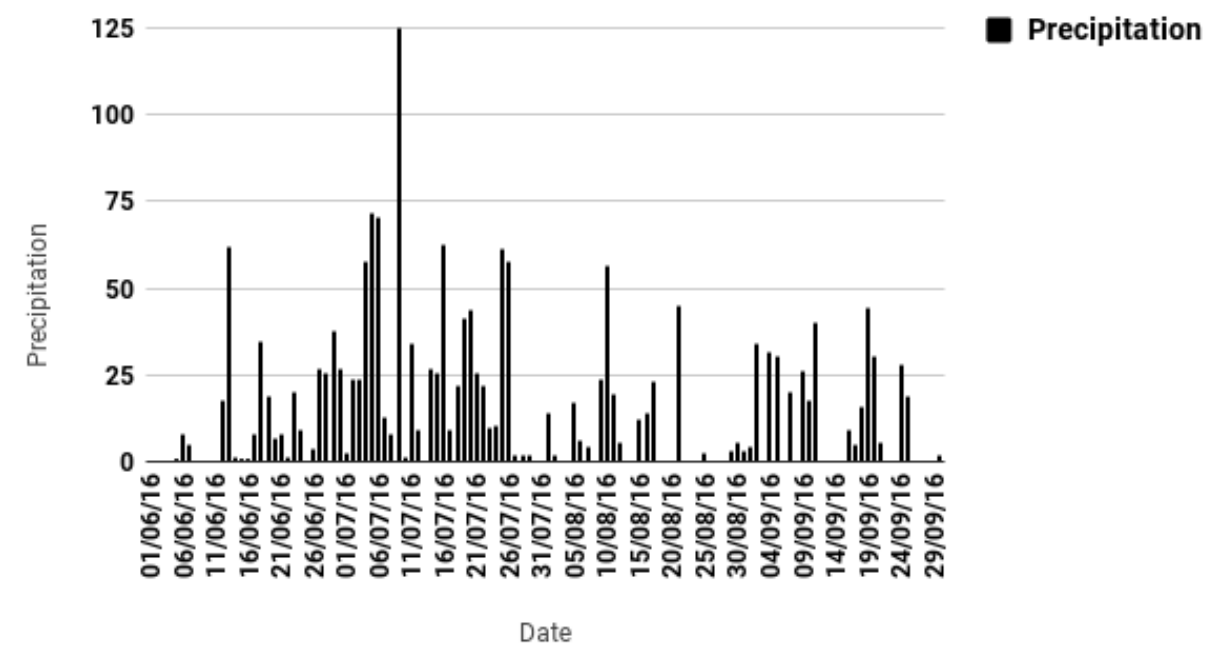


Nat. Hazards Earth Syst. Sci. Discuss., https://doi.org/10.5194/nhess-2017-295

Manuscript under review for journal Nat. Hazards Earth Syst. Sci.

Discussion started: 28 August 2017

(C) Author(s) 2017. CC BY 4.0 License.

\section{Mobility Function $\mathrm{Y}(\mathrm{t})$ vs Date}

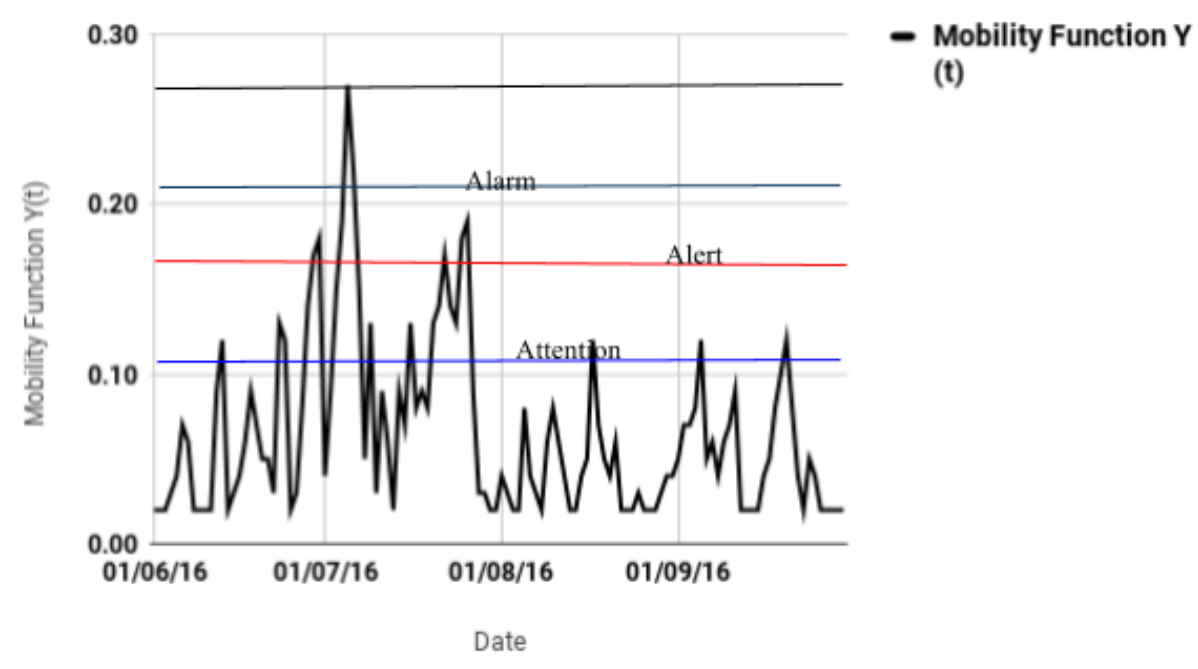

(b) Mobility function between 01 June 2016- 30 September 2016

Figure 12(a,b): Precipitation values and its corresponding mobility values from 1 June to 30 September 2016

The number of warning status provided by FLaIR model for 2016 monsoon analysis are:

Alarm $\left(\mathrm{Y}_{\mathrm{cr}}=0.8 \mathrm{Y}_{\text {lim }}\right)=3$

Alert $\left(\mathrm{Y}_{\mathrm{cr}}=0.6 \mathrm{Y}_{\text {lim }}\right)=6$

Attention $\left(\mathrm{Y}_{\mathrm{cr}}=0.4 \mathrm{Y}_{\mathrm{lim}}\right)=14$

From this analysis, it is observed that there were 3 probable landslide events where alarm was required (Fig. 12b) during 2016 monsoon in Chibo Pashyor region which is in conjunction with the actual landslide event. This study will help in generating alarm taking local rainfall conditions and help in saving human lives and property.

\section{Conclusion}

In this paper, application of hydrological model FlaIR for the forecasting of landslides triggered by rainfall is demonstrated. It focuses on forecasting landslide movements depending on antecedent rainfall events. The area of focus is Chibo located in Kalimpong in the state of West Bengal, India. The analysis for landslide occurrence on $1^{\text {st }}$ July 2015 shows the maximum value of the mobility function as 0.27 . This value suggests that the landslides will occur when the mobility function exceeds the maximum value. The result suggests that advance analysis in the Chibo Pashyor area can lead to the determination of transfer function. Based on the lithology involved in the process, significant parameters such as transfer function, mobility function etc are able to depict the relationship between rainfall and landslide events.

360 The reliability of the model depends on parameter calibration which is based on time series of rainfall data and landslide event. The results obtained using the model is integrated with a probabilistic model for predicting rainfall at hourly scale. Six tiltmeters have been recently installed in the region which would help in understanding the landslide activity. This would help in improvement of results and help in other applications of 
Nat. Hazards Earth Syst. Sci. Discuss., https://doi.org/10.5194/nhess-2017-295

Manuscript under review for journal Nat. Hazards Earth Syst. Sci.

Discussion started: 28 August 2017

(c) Author(s) 2017. CC BY 4.0 License.

the FLaIR model by correlating the mobility function $\mathrm{Y}($.) to field data pertaining to the movement of landslides or changes in pore pressure.

\section{References}

1. Beniaminos Sirangelo and Pasquale Versace (1996) A Real Time Forecasting Model for Landslides Triggered by Rainfall Meccanica 31: 73-85,

2. Michiue M (1985) A method for predicting slope failures on cliff and mountain due to heavy rain. J Nat

Disaster Sci 7(1):1-12

3. Giovanna Capparelli and Pasquale Versace (2011) FLaIR and SUSHI: two mathematical models for early warning of landslides induced by rainfall Landslides. Springer (2011) 8:67-79 DOI 10.1007/s10346-010-0228-6 4. Giovanna Capparelli and Davide Tiranti (2010) Application of the MoniFLaIR early warning system for rainfall-induced landslides in Piedmont region (Italy).Springer (2010) 7:401-410 DOI 10.1007/s10346-009-0189-9

5. Caine N (1980) The rainfall intensity duration control of shallow landslides and debris flows. Geogr Ann 62:23-27

6. Versace P, Sirangelo B, Capparelli G (2003) Forewarning model of landslides triggered by rainfall. In: Proceedings of the III International Conference on Debris-Flow Hazards Mitigation, Mechanics, Prediction and

380 Assessment, Davos, 2, pp 1233-1244

7. Sirangelo B, Versace P (1996) A real time forecasting for landslides triggered by rainfall. Meccanica 31:1-13

8. Sirangelo B, Versace P, Capparelli G (2003) Forewarning model for landslides triggered by rainfall based on the historical data file. In: Proceedings of International Symposium on Hydrology of the Mediterranean and Semiarid Regions, Montpellier, IAHS, 278

385 9. Wilson RC, Wieczorek GF (1995) Rainfall thresholds for the initiation of debris flow at La Honda, California. Environ Eng Geosci 1(1):11-27

10. Abhijit Mukherjee et.al (2001) Geotechnical study of mass movements along the Kalimpong approach road in the Eastern Himalayas. Indian Journal of Geology Vol. 73, No. 4, p. 271-279, 2001.

11. Causes of Landslides in Darjeeling Himalayas during June-July, 2015 Sumantra Sarathi Biswas and 390 Raghunath Pal Jawaharlal Nehru University, New Delhi, India.

12. T.B. Ghoshal, N.K. Sarkar, Saibal Ghosh and M. Surendranath (2008) GIS Based Landslide Susceptibility Mapping- A Study from Darjeeling-Kalimpong Area, Eastern Himalaya, Kolkata Journal Geological Society of India Vol.72, December 2008, pp.763-773.

13. Sandipan Ganguly Palash Patra Avijit Guray (2015) A study on Landslides and subsidence along National

395 Highway 31 A, Darjeeling District, West Bengal. Journal of International Academic Research for multidisciplinary ISSN: 2320-5083, Volume 3, Issue 6, July 2015.

14. Subhash Ranjan Basu and Sunil Kumar (2003) Causes and consequences of landslides in the DarjeelingSikkim Himalayas, India De Geographia Polonica, 76, 2, 37-52, Autumn 2003, PL ISSN 0016-7282.

15. Biswajit Mondal and Malay Kumar Pramanik (2016) Landslides and Floods in the Tista Basin (Darjeeling

400 and Jalpaiguri Districts): Historical Evidence, Causes and Consequences Raghunath Pal, Sumantra Sarathi Biswas , J. Ind. Geophys. Union ( April 2016 ) v.20, no.2, pp: 209-215

16. Gerrard J (1994) The landslide hazard in the Himalayas: geological control and human action. Geomorphology 10: 221-230.

17. McGeary, David, Charles C. Plummer and Diane H. Carlson ; 2001; Physical Geology: Earth Revealed. 405 Boston: McGraw-Hill.

18. Rajakumar R, Sanjeevi S., Jayaseelan S., Isakkipandian G., Edwin M., Balaji P. and Ehanthalingam (2007); Landslide Susceptibility Mapping in a Hilly Terrain using Remote Sensing and GIS; Journal of the Indian Society of Remote Sensing, Vol. 35, No. 1, 2007.

19. Chakraborty I, Ghosh S, Bhattacharya D, Bora A (2011) Earthquake induced landslides in the 410 Sikkim-Darjeeling Himalayas- An aftermath of the 18th September 2011 Sikkim earthquake. Kolkata: Geological Survey of India.

20. Aleotti P (2004) A warning system for rainfall-induced shallow failures. Eng Geol 73:247-265 
Nat. Hazards Earth Syst. Sci. Discuss., https://doi.org/10.5194/nhess-2017-295

Manuscript under review for journal Nat. Hazards Earth Syst. Sci.

Discussion started: 28 August 2017

(c) Author(s) 2017. CC BY 4.0 License.

21. M. T. Brunetti,S. Peruccacci, M. Rossi, S. Luciani, D. Valigi and F. Guzzetti (2010), C.P: Rainfall thresholds for the possible occurrence of landslides in Italy Nat. Hazards Earth Syst. Sci., 10, 447-458,2010 www.nat-hazards-earth-syst-sci.net/10/447/2010/

22. Guzzetti, F., Peruccacci, S., Rossi, M., and Stark, C. P.: The rainfall intensity-duration control of shallow landslides and debris flows: an update, Landslides, 5(1), 3-17, 2008.

23. Guzzetti, F., Salvati, P., and Stark, C. P.: Evaluation of risk to the population posed by natural hazards in Italy, in: Landslide risk management, edited by: Hungr, O., Fell, R., Couture, R., and Eberhardt, E., Taylor \& Francis Group, London, 381-389, 2005a.

24. Sirangelo, B., Braca, G., 2004. Identification of hazard conditions for mudflow occurrence by hydrological model. Application of FLaIR model to Sarno warning system. Engineering Geology 73, 267-276 http://dx.doi.org/10.1016/j.enggeo.2004.01.008.

25. Ranit Chatterjee (2010) Landslide Hazard Zonation Mapping of Kalimpong, Publisher : VDM Verlag Dr. Muller GmbH \& Co. KG.

26. De Luca, D. L. and Versace, P.: Diversity of Rainfall Thresholds for early warning of hydro-geological disasters, Adv. Geosci., 44, 53-60, https://doi.org/10.5194/adgeo-44-53-2017, 2017

27. De Luca, D. L. and Versace, P A comprehensive framework for empirical modeling of landslides induced by rainfall: the Generalized FLaIR Model (GFM). Landslides 2016, DOI 10.1007/s10346-016-0768-5 